\title{
Education Migration among Africans: A Case Study Of Nigerian Postgraduate Students InInternational Islamic University Malaysia
}

\author{
AbdullahiMohd Umar \\ Department of Sociology and Anthropology Kulliyyah of Islamic Revealed Knowledge \& Human Sciences \\ International Islamic University Mala
}

\begin{abstract}
The research paper attempts stress the importance of education and also clarify the factors influencing African postgraduate students to undertake higher education studies abroad. In the recent times, Asia pacific is one of the attracting region for the African students particularly, Malaysia. A sample of 90 international postgraduate students from Nigeria studying at International Islamic University Malaysia (Gombak main campus) were selected as informants and their experiences and views was used in the analysis of data collected.

The results show that conditions in both the students' countries of origin and that of the hosting countries contributed to the decision to study abroad. Of prime importance among the factors attracting students abroad is the poor condition of learning, political instability in the continent and lack of basic infrastructure like lecture rooms, student accommodation, power supply, portable water, inadequate manpower, laboratories, equipments and other learning facilities in the higher education sector were identified as push factors. On the other hand, migration to Malaysia was influenced by the availability of infrastructure, learning facilities, manpower, moderate tuition fees, affordable cost of living and above all being Muslim country further serves as motivator for the international student migration.
\end{abstract}

\section{Introduction}

This study tries to enumerate the importance of education and the growing trend in education migration among African students with specific reference to Nigerian students. Though the phenomenon of education migration is not a new thing, is something that is being practice many years back. But in the recent times there is rapid increase in the trend, many governments and well-to-do individuals in Africa had to award sponsorships and scholarships to several students to study abroad.Maringe and Carter (2007: 17) stated that there is no comprehensive statistical data on the exact number of African education migrants to other parts of the world. However, there is substantial increase in the number of African students in many European higher education Institutions. Educational migration and international studentship in recent times have been attracting phenomena to many people across the world. Though is difficult to have a comprehensive figure but it is belief that African continent has experienced a steady increase in the last four decades, the number of students migrating for the sake of seeking post-graduate education abroad, predominantly in the OECD countries Spring (2009: 32). Also it has been reported that, the number of African students studying abroad has increased from 2,580 in 1970 to over 1.8 million in 2002 (Africa Statistical Year Book, 2002: 45). In the UK alone in 2002, the number of African students studying in various higher education institutions was estimated at 66,000 students. The figure suggests that one in every 15 international students comes from Africa (Africa Statistical Year Book, 2002: 45). The UK is the most favoured destination for the African students particularly those from the West African states. Other destinations sought were Australia, the US, Canada, France, Germany and New Zealand (Dzvimbo, 2003: 18-19). Scholars have attributed a range of reasons that could have contributed to this phenomena among Africans as far as education migration is concerned. For this, it is important to examine briefly some vital issues surrounding education and migration in the context of Africa.

Also according to the Governor of Central Bank of Nigeria, MallamSanusiLamidoSanusi, Nigerians have spent over USD1 billion annually in foreign education (CBN Report February, 2012). It has been reported in several literature that migration among Africans is related to lack of basic infrastructures in the educational systems of many African countries (Adepoju, 2008: 42; Augusta\& Augusta, 2008: 32 and Rodney, 1972: 115). Adepoju (2008: 43) states that international students' migration in most parts of Africa is due to the deteriorating state of internal conditions, for instance, lack of basic infrastructure and modern facilities to meet the demands of their education systems. Augusta and Augusta (2008: 24) also attributed education migration among Africans to political instability in the region and lack of development in education and other sectors that can allow them to face the challenges posed by globalization and the globalizing world. On the other hand, 
Rodney (1972) argues that education is deliberately underdeveloped in all colonized regions of Africa so that the colonial legacy of exploitation will continue indefinitely. Rodney further argues that the education provided was only to train few individuals in administrative education in order to serve the colonial power during and after the colonial era.

In 2000 a survey conducted by Task Force on Higher Education and Society, indicated that Africa has no more than 300 institutions that fit the definition of a university. By international standards, Africa is the least developed region in terms of higher education institutions and enrollments. While a few countries on the continent can claim comprehensive academic systems, most have just a few academic institutions and have not yet established the differentiated postsecondary systems required for the information age (Task Force on Higher Education and Society 2000:23). Thus, African students migrate abroad in search of education a tradition which existed since colonial period to present day.

This is a study conducted in International Islamic University Malaysia (IIUM) Gombak main campus, focusing on Nigerian postgraduate students; on push and pull factors and challenges of education migration.

\section{Contemporary Education and Migration}

Merriam Webster Dictionary (2009) defines education as a action or process of educating or of being educated; alsoa stage of such a process, b) the knowledge and development resulting from an educational process c)the field of study that deals mainly with methods of teaching and learning. The concept of migration, on the other hand, refers to cases where the decision to migrate is taken freely by the individual concerned for reasons of personal convenience, without intervention of an external compelling factor (International Organization for Migration, 2010: 4). In addition, the United Nations Report (2006: 12) defines a migrant as an individual who has resided in a foreign country for more than one year irrespective of the causes, either voluntary or involuntary and regular or irregular. Under such a definition, those travelling for shorter periods as tourists and business-persons would not be considered as migrants.

According to Jackson (1969: 34) migration refers to a permanent or semi-permanent change of residence by an individual or group. The migration could be for a specific material reason or other purposes. Jackson further explains that permanent migration implies permanent change of residence while semi-permanent migration implies temporary change with a view of returning to one's native settlement or homeland. Tadaro (1976: 34) on the other hand, classifies migration into two broad forms, namely, "internal" and "external migration". Internal migration deals with migration within the borders of a particular country. External migration refers to cross-border or international migration that involves moving out of one's country with a view of settling in another country for a long period of time. In this case, the huge population of white settlers in South and East African regions and the presence of Arab merchants and traders in some West African countries during the Era of Trans-Sahara trade which has now accorded them the status of full citizenship are clear examples of external and permanent migration.

\subsection{Education Migration}

Scholars have been using different concepts and terms in referring to the migration phenomenon particularly of education migration. A time is referred to as international student migration or internationalization. There are also other concepts often used in relation to education migration, concepts like transnational education, cross-border education, international education, international student mobility, international mobile student, student migrant, foreign student education or foreign student mobility are being used interchangeably. All these concepts highlighted above are fundamentally the same and virtually all of them are addressing the same subject matter (Knight, 2003: 2). For the purpose of this study, the two concepts, education migration and international student migration will be used side by side.

For UNESCO, international students refer to students who have crossed a national or territorial border for the purpose of education and are currently enrolled outside their country of origin (UNESCO, 2006: 178). In addition, international students are also referred to as the ones who undertake all or part of their higher education experience in a country other than the home country (Project Atlas, 2004). At this juncture, it is imperative to distinguish between ISM and other similar phenomena such as migrant education, emigrant education or professional migration, which may likely be confusing to people who are not familiar to migration studies. It should be understood that migrant education and emigrant education are centrally concerned with providing educational opportunities for the families and dependents of those who migrate from their country of origin either for economic, social or political reasons to settle in another country. Their migration however, is not in any way related to education or educational pursuits as the main motivator for their migration. Professional migration, the concept refers to migration of people who possess professional skills or training such as medical doctors, nurses, mid-wives, engineers, lawyers or teachers who decide to migrate permanently to a second country. The motivational factors for their migration are very much affected by better income and welfare issues. At times is also referred to as 'brain-drain' (Abdullahi, 1998: 31). The concept of brain-drain 
was originally coined by the British to express loss through emigration of large numbers of skilled professionals (Altbach, 2003: 21).

It is a well known fact that education migration is a global trend and not limited to students from Africa only. It is reported that over the past 10-15 years, education migration has become an increasingly important aspect for the international higher education landscape particularly for the Organization for Economic Cooperation and Development (OECD) countries. It is estimated that in 2005 more than 2.7 million people (about 61\% increase since 1992) have migrated to other countries for education. In this case more than $90 \%$ of international students have enrolled in institutions belonging to OECD countries with main destinations such as the US, the UK, Germany, France and Australia (Verbik\&Lasanowski, 2007).

\subsection{Globalization and Education Migration}

Castles and Miller (2003: 23) in their study on globalization and migration found that the connection between immigration and globalization is so powerful and has been present for the last 50 years. Scholars had defined globalization from different perspectives. A famous sociologist Anthony Giddens(1997: 19) for instance, defined globalization as an intensification of worldwide social relations which link distant localities in such a way that local happenings are shaped by events occurring many miles away and vice-versa. Waters (2001: 5) sees globalization as a social process that creates geographical constraints on economic, political, social and cultural arrangements recede, in which people become increasingly aware that they are receding and for which people act accordingly. For Robinson (1991: 1) globalization is a dynamic process of growing interdependence among nation states, with the implication that issues are becoming global rather than national. In addition, Ajayi (2002: 20) notes that the globalization process is facilitated by new knowledge and information flow. Knowledge has become the most valuable commodity in the present global economy, which is entirely different from previous international economies.

\subsection{Impact of globalization on EducationMigration}

Globalization has brought a new vision of seeing students as human capital (Apple, 2000: 60). The vision and theory of human capital stimulated international student migration from developing countries to developed countries for a better education in order to strengthen themselves in the competitive labour market (Marginson, 1997:43).Habu (2000: 23) states that there are four particular factors that motivated this growth. Firstly, the globalization of economies and many businesses has created the need for those businesses to link with international education experiences via an international network. Secondly, the demands for broader cultural experience and language training have been increasing. Thirdly, the growth of expert knowledge has created an opportunity for international higher education institutions. Finally, an increase of income levels in some developing countries has stimulated the demands for international higher education service. Barrow, et al (2003) stated that the influence of globalization and knowledge economy has significantly promoted the trend in international higher education.Adewusi (1997: 43) in his book entitled "Impact of Globalization on Education", points out that globalization has affected education in two broad dimensions; commercialization of education and productive education. Commercialization of education refers to turning schools as avenue for income generation and modern form of investment where huge amounts of money are invested to procure modern gadgets and facilities with the sole objective of realizing a huge turn over. On the other hand, productive education represents market-force as the sole driver for education. People are trained professionally for specific productive activities in order to meet market demands, especially in present era of advanced technology of production and communication.

\section{Push and Pull factors for African Education Migration}

Adewusi (1997) argues that is difficult to most governments in Africa to provide all their population's with the modern high educational needs, it must look outward to meet the contemporary challenges. In most African countries, university education are becoming highly expensive and beyond affordable for the majority of the citizens. Teferra and Abatch (2003) posit that the inadequacy in Africa's higher education originated from the period of colonialism. Various colonial authorities in Africa deliberately embarked upon a policy of not encouraging higher education in the region. The colonial government adopted a policy of sending few individuals to their respective metropolis, notably, Britain, France, Belgium, Portugal, German, Italy and Spain in order to acquire higher education. They were interested in training limited numbers of African nationals to assist in administering the colonies. Some colonial powers, notably the Belgians, forbade higher education in their colonies. Others, such as the Spanish, French and the Portuguese, kept enrollments low (Teferra and Altbach,2003: 23). Slaughter \& Rhoades, (2004: 21) state that some view international students as revenue sources and cheap skilled labour particularly in the sciences and engineering. Meanwhile Maringe and Carter (2006) developed a model for African students studying in England, in their study they foundthat decision by Africans to study abroad was very much influenced by the push and pull factors. The push factors concentrated 
on three important factors namely, politics, economy and home country capacity. The pull factors include international recognition of a UK degree, high quality education, safe environment, easy application process, marketability of courses applied and labour market viability.

\subsection{Educational Dependency and Structural Constraints in Africa}

One aspect that contributes to the inadequate, access and poor state of higher education in Africa is educational dependency. This involves sponsoring student from developing countries to obtain higher degrees abroad after the Second World War by OECD countries (Offiong, 1980: 83). Many Western governments, particularly from developed countries have been sponsoring students from developing countries in order to study abroad in various professional fields. The Australian government, for instance, introduced the Colombo Plan since 1950, the plan was supporting and sponsoring students to study in Australia until 1980's. The main objective of the plan was to promote interest and support for the economic and social development in developing countries, through educational training, trade, technical support and manpower development (NAFSA, 2001: 12).Rodney (1972), previous policies of colonial administrations in the African region such as the deliberate refusal to develop higher education, lack of access to higher education, inadequate funding, mismanagement and poor governance remain as inherited legacies in the region. Most African governments adopted and continue with the previous patterns of funding higher education in Africa. Others like Barrow, DidouAupetit\&Mallea (2003) attribute the inadequacy of higher education in Africa to structural policies of international economic regulatory organizations. Thus, includes the role of IMF and the World Bank, UNESCO and OECD countries in influencing, interfering and shaping most of Africa's internal policies including educational policies. In many instances, they encourage promoting only basic literacy education such as primary and post-primary education as the major focus in order to achieve only basic mass literacy. Another important factor that has recently been discovered to contribute to the deplorable condition in many Africa's higher institutions is professional migration or brain-drain it is reported that since 1990, Africa has been losing approximately 20,000 professionals in different fields of specialization annually (IOM: 2004: 46).

However, Altbach (2004:26) concludes that there are some political motives behind higher education beside economy interests of the developed worlds. Albach, believes that political and ideological factors have been playing a crucial role in sending students from developing countries abroad for high education. He further claims that industrialized nations view higher education as another battleground for the "hearts and minds" in the world particularly, in Third World countries. Assistance programmes, scholarships, book aid, provision of foreign aid, and other initiatives were all seen as part of the Cold War political strategies. One cannot forget that national interests and agendas, on all sides, are involved in academic cooperation (Altbach, 2004: 32).

\section{The Duo Benefits of Education Migration}

It is evident that education migration has great benefits to both the sending and the receiving countries. According to Kemp (2007: 23) the market for international students is one of the most dynamic of all world markets. The last ten years has seen such an unprecedented growth that governments from a range of countries now prioritize involvement in this market through their own ministries of education or dedicated international education promotional agencies. The potential benefits of having international students are linked to skill migration, economic growth, public diplomacy and more importantly to research and innovation for a knowledge society Kemp (2007:23). Drucker (1994) posits the concept of knowledge society is widely used by development scholars to describe the replacement or shift in traditional labour and capital as main factors to the production of knowledge as the most important and fundamental factor in contemporary globalized world. Ismail and Ismail (2003:34) stated that the transformation in modern society has made the role of knowledge greater and more crucial than ever before.

Robertson and Keeling (2008: 221) also observe that in many parts of the world higher education is viewed as a prime 'motor' for the development of a knowledge-based economy. Under the banner of this 'new economy', higher education policies, programmes and practices have been increasingly co-opted and shaped by wider geostrategic political and economic interests. In other words, higher education in modern times has not only become an important tool, but is a necessary requirement to obtain the desired skills needed in order to be able to compete in the globalizing world (Robertson \& Keeling, 2008: 221).

The Australian government for example, has identified the international higher education service as the most profitable andrapidly growing export industry. It contributed AUD5 billion in 2003, and at the same time, created over 42,000 jobs for the Australian economy (NAFSA, 2003). In the US the international students have provided significant revenue not just to the host campuses but also to local economies of the host state from living expenses, including room and board, books and supplies, transportation, health insurance, support for accompanying family members, and other miscellaneous expenses (Open Doors, Report, 2010).

Gribble (2008: 25) emphasizes that the contributions that foreign students make to host nation economies, both culturally and financially, have encouraged major players to implement further initiatives to 
facilitate the arrival and integration of overseas students, including substantial amendments to immigration, visa policies and procedures.

\section{Malaysian Influence in the Trend}

It is interesting to report that Malaysian higher education institutions are able to secure international students from many developing countries in Asia, the Middle East and Africa. As a result, the number International studentscoming to Malaysia has been increasing steadily since 2001 especially after the famous September 11, 2001 (Verbik and Lasanowski, 2007: 28). The September,11 or 9/11 event that took place in the US in 2001 has gave Malaysia a comparative advantage by getting more number of international students patronizing its education (Verbik and Lasanowski, 2007: 28). After the 9/11 the US government has intensified its immigration policies, process and procedures for migrants including international students as a result that the student intake dropped with approximately 4-6\% (NAFSA 2004).

The steady enrollment rate of the international students has motivated the Malaysian higher education sector in its National Higher Education Action Plan, 2007-2010to project and target of 100,000 foreign students by 2010. For this, a study on international students was conducted in 2008/09 initiated by the Education Promotion Division, Department of Higher Education. The study indicates that as of 2008, Malaysia had 69,164 foreign students with a steady growth of $16.8 \%$ and in 2009 , Malaysia had 80,750 foreign students with African studentsconstituting approximately 20\% (PerangkaanPengijianTinggi Malaysia, MOHE,2009).

The study found that the education migration toMalaysia has connection with economic, social and political factors prevailing in that country as a driving force, influencing education migration. It reveals that certain important factors such as affordable school fees, political stability, proximity or geographical location, relaxed visa policies and average living expenses in Malaysia have continued to attract a wide range of students from Asia, Africa and the Middle East (PerangkaanPengajianTinggi Malaysia MOHE, 2009).

However, according to the International Labour Organization (ILO) there is a mix view on public perception of migrants as either positive or negative ambassadors depending on individual countries. A surveyconducted across some selected Asian countries including, the Republic of Korea, Malaysia, Singapore and Thailand by the International Labour Organization (ILO) in 2010 "On how migrant workers were being perceived by the local population" in those countries. The survey shows that the majority of the respondents believed that migrant workers were needed to fill labour shortages. An average of $80 \%$ in the Republic of Korea and Singapore believed that migrant workers made a net contribution to the economy; $40 \%$ in Thailand and $38.6 \%$ in Malaysia also felt the same way (ILO, 2010:19). However, according to the international Organization for Migration (IOM), there was misconception about these migrants due to distorted information shown by the mass media. As a result, this inadvertently affects government policy in dealing with migrants. One of the biggest challenges in this regard is what and how governments communicate about migrants and migration policy to the wider public and society at large. Informing and educating the public may be the single most important policy tool in all societies grappling with migration, since managing migration also involves managing how migrants are perceived in society (World Migration Report, 2011: 12).

The foregoing literature has addressed several issues surrounding education and migration. There are many factors responsible for international student migration. These factors include the political instability in Africa (Nigeria), economic opportunities in other countries, the impact of globalization on education, the emergence and transformation of economies and societies to knowledge society which compel a new look to educational system. In addition, other factors also examine the persistent inadequacy of higher education in many developing countries had also attracted the trend of education migration.

\section{Conclusion}

The summary of the research reveals that the higher education in Nigeria suffers from numerous problems confronting the sector. Those problems were classified into two broad categories. They are basically attributed to political and socio-economic factors.The political factor has to do with the unstable political administration and poor governance in Nigeria, which led to underdevelopment of many institutions particularly, educational institutions in country. It was discovered that from the collapse of first republic between 1960 to 1966 Nigeria has experienced many different military and civilian regimes, all the regimes come to power with different priority. Unfortunately none of those regimes had taken the issue of education so serious like the previous regional governments that was sustained for only six years (1960-1966) that marked the systematic beginning of problems of higher education in Nigeria. Another major problem identified was poor funding, the under- funding of education by successive regimes had adversely affected the sector in all its ramifications. The budgetary allocation to education in Nigeria is not up to fifty percent of the UNESCO's recommendation of 26 percent of the national budget. What the governments allocate to education in Nigeria was between 11 to 12 percent of the national budget which is far below what is recommended to boast the sector. The long time under-funding of higher education sector especially by military regimes has worsened the 
entire higher education system leading to poor quality education with predominantly "half-baked graduates" poor quality graduates.

The research found that one of the fundamental reason that compelling Nigerian students to travel abroad for higher education is due to poor state of higher education in Nigeria. The poor funding issues had affected almost all areas of higher education institutions in Nigeria, making it difficult to produce capable postgraduates. Teaching and learning facilities were grossly inadequate almost in all the universities. Also there is problem of non-commitment to duty by some academic staff, the postgraduate student receive less attention from their respective supervisors. The research revealed that many senior academic staff engaging themselves in multiple part time academic jobs to the detriment of their primary employer.

Malaysia attracted many Nigerians because of affordable school fees, affordable living expenses, quality education, simple visa procedure and most importantly for being Islamic country as motivating factor to Malaysia. The strict visa policies introduced in Europe and America couple with the growing threat of Islamaphobia in the West and other non-Muslim countries after the popular September, 11 event had also attracted many Nigerians to Malaysia.

\section{Bibliography}

[1]. Abdullahi, A. (1998). Migration among young people in Sub-Sahara Africa: Challenges and Prospects. Arewa Journal of Social Sciences, 3, 3-17.

[2]. Adepoju, A. (2008). Perspectives on International Migration and National Development in sub-Saharan Africa, in A. Adepoju, T. van Naerssen and A. Zoomers (eds) International migration and national development in sub-saharan Africa: viewpoints and policy initiatives in countries of origin, Leiden: Brill.

[3]. Adewusi, S. A. (1997). Impact of Globalization on Education: An African perspective. Thomas and Johns, Publishers, Ibadan, Nigeria.

[4]. Africa Statistical Year Book. (2002). Africa Statistical Year Book,Vol. 2, UN Publications, New York, NY.

[5]. Ajayi, A. (2002) Globalization and the Nigerian Manufacturing Sector. Paper presented at annual meeting of manufacturers Association of Nigeria (MAN).

[6]. Altbach, P. (2003). Foreign Study: Changing Patterns and Competitive Challenges. International higher education, 30, 2-3.

[7]. Altbach, P. (2004). Globalization and the University: myths and realities in an unequal world. tertiary education and management, 10(1), 325

[8]. Apple, M. W. (2000). Between Neoliberalism and Neoconservatism. In N. C. Association of Universities and Colleges of Canada (AUCC). (2002). Study Abroad backgrounder. RetrievedAugust4,

2012,http://www.aucc.ca/_pdf/english/reports/2002/innovation/study_abroad_e.PDF

[9]. Augusta O, and Augusta, A. (2008). The Social and Economic Impact of Forced Migration: African student experience abroad. Thomas and Johns publishers, Ibadan, Nigeria.

[10]. Barrow, D. W., Didou-Aupetit, S., \&Mallea, J. (2003). Globalization, trade liberalization, and higher education in North America: The emergence of a new market under NAFSADordrecht, the Netherlands: KluwerAcademic Publishers.

[11]. Baláž, V. \& Williams, A. M. (2004), 'Been there, done that': international student migration and human capital transfers from the UK to Slovakia. Popul. Space Place, 10: 217-237. doi: 10.1002/psp.316

[12]. British Council 2003.Vision 2020: Forecasting international student mobility - AU perspective, 4

[13]. British Council 2004. Going Global. The UK International Education Conference, 8-10 December,2004. Edinburgh, Scotland. Retrieved December 31, 2007, from http://www.britishcouncil.org/.

[14]. Brown, K. \& Bean, D. (2005) Trends of international migration: What existing data reveal. International Migration. Published by N Y Publishers.

[15]. Castles, S. and Miller, M. (2003). The age of migration. Third edition, Guildford Press, New York.

[16]. Central Bank of Nigeria Report, Vol-13-2 (2012) Published by FCT Press, Abuja, Nigeria.

[17]. Cross-border Tertiary Education A Way towards Capacity Development . OECD Publishing/The World Bank (2004).

[18]. Crush, J. (2009). The South African Diaspora and the Diaspora in South Africa: Implications for research, policy and development.paper presented to international conference on diaspora for development. World Bank, Washington.

[19]. Davey, G (2005). Chinese students' motivations for studying abroad. International journal of private Education, 2, 16-23

[20]. Drucker, P. F. (1994) Post-capitalist Society. New York: Harper Bussiness.

[21]. Dzimbo, P.K. (2003). The international migration of skilled human capital from developing Countries. Paper presented at a case study for a World bank conference.

[22]. Evers, H. (2001). Towards a Malaysian Knowledge Society. Working Paper No 20, Bangi: Institute of Malaysian and International Studies (IKMAS) National University of Malaysia.

[23]. Encyclopædia Britannica, Propædia: Outline of Knowledge and Guide to the Brittanica. 15th edition, 2005.

[24]. Giddens, A. (1997). The Globalizing Modernity, in David Held and A. McGrew (eds.) The Global Transformations Reader An Introduction to theGlobalization Debate, Cambridge: Polity Press.

[25]. Gürüz, K. (2008). Higher education and international student mobility in the global knowledge economy. Albany: State University of New YorkPress.

[26]. Gribble, C. (2008). Policy options for managing international student migration: the sending country's perspective. Journal of Higher Education Policy and Management, 30 (1), 25- 39

[27]. Habu, T. (2000). The Irony of Globalisation: The Experience of Japanese Women in British Higher Education. Higher Education, 39, 43-66.

[28]. International Organisation for Migration Report (2004) Vol 13- No-1-6. New York Office, USA.

[29]. International Labour Organization (ILO: 2001). Handout, International Migration, Racism, Discrimination and Xenophobia. Publication for distribution at the World Conference against Racism.

[30]. International Labour Organization Quarterly Report, Vol 34-3 (ILO: 2010).Published by theILO office in Geneva, Switzerland.

[31]. International Labour Organization (ILO)/International Organization for Migration (IOM)/Office of the High Commissioner for Human Rights (OHCHR), Geneva. See: http://www.ilo.org/public/english/protection/migrant/download/wcar.pdf (accessed on 24 August 2011)

[32]. Ismail, R. \& Ismail, M. (2003) African Higher Education: The problems and prospects.paperpresented at international conference organised by faculty of social sciences University of Maiduguri 23-27 March,2007.

[33]. Jackson, E. (1969). Age of Migration and Emergence of Urbanization in the $20^{\text {th }}$ century.published by Quebec press Ltd. Canada

[34]. Szelenyi, K. (2006). Knowledge. Technology \& Policy Fall. A conference paper, Presented at

[35]. international conference on technology development, Rome, 2006.Italy.

[36]. Kelly, G. \&Altbach, P. (2004). Introduction: The Four Faces of Colonialism. In G.Kelly\& P. Altbach (Eds.), Education and the Colonial Experience.New Brunswick: Transaction, 1984. 1-5 
[37]. Kemp, N. (2007). International education and the global market. Quoted from Kishun, R. (2006). The internationalization of higher education in South Africa: Progress and challenges. Durban, South Africa: Astro Printers. IEA of South Africa.

[38]. Kishun, R. (2006). The internationalization of higher education in South Africa: Progress and challenges. Durban, South Africa: Astro Printers. IEA of South Africa.

[39]. King, R. \& Ruiz-Gelices, E. (2001). Human Mobility in Borderless World. Paper Presented at the First International Conference of the International Geographical Union's Globility study group on ' Human Mobility in a Borderless World', LaretoAprutino, Italy 20-21 April, 2004.

[40]. Knight, J. (2003). Updating the Definition of Internationalization. International Higher Education, 33, 2-3

[41]. Lee, E. S. (1966). A Theory of Migration. University of Pennsylvania. JSTOR 2060063

[42]. Mahathir, M. Speech delivered in Malaysian Business Council 28 february, 1991. Quoted from Evers, Hans-Dieter. (2001), Towards a Malaysian Knowledge Society, Working Paper No 20, Bangi: Institute of Malaysian and International Studies (IKMAS) National University of Malaysia.

[43]. Maringe, F., \& Carter S. (2007) International students' motivations for studying in the UK HE: Insights into the choice and decision making of African students. International Journal of Education Management, 21 (6) 458-459

[44]. Marginson, S. (1997). Markets in education. Sydney (Australia): Allen and Unwin.

[45]. Marginson, S. \&Sawir, E. (2005). Interrogating global flows in higher education. Globalisation, Societies and Education, 3 (3), 281-309

[46]. The Merriam Webster Unabridged Dictionary Online; www.analyrics.com/ lyrics

[47]. Marginson, S. (2006). Dynamics of national and global competition in higher education. HigherEducation 52,1-39.

[48]. Ministry of Higher Education (MOHE) 2010. Compilation of statistics.Putrajaya: Ministry of Higher Education. [49]. Morshidi, S. 2008. Trends in International higher education and regionalism: Issues and challengesfor Malaysia.paper presented at
Waseda GARI International Symposium on Asian Cooperation, Integration, and Human Resources, Waseda University, 17 and 18 January 2008.

[50]. NAFSA (2001) Association of International Educators: Overview and Background. Retrieved October 11, 2008 from http://www.nafsa.org/knowledge_community network.

[51]. NAFSA (2004) Association of International Educators. The Economic Benefits of International Education to the United States of America: A Statistical Analysis, 2002-2003. Retrieved August 3 2008, from http://www.nafsa.org/public_policy.sec/international_education_1/

[52]. Offiong, D. (1980). Imperialism and Dependency.Malthouse Publishers, Ibadan Nigeria.

[53]. Open Doors. (2006). Report of International Education Exchange. New York: Institute of International Education.

[54]. Organization for Economic Development and Cooperation (OECD) \& World Bank. (2007). Education policy analysis: Focus on higher education. Paris: OECD publications.

[55]. Project Atlas. (2004). Outcome of International Student Mobility Conference, April 21-23,2004, Tours, France. Organized by the Institute of International Education, (Atlas of Student Mobility) Http://www.atlas.iienetwork.org/

[56]. Petersen, C. (1975). The Age of Migration: A Global Phenomenon. International Journal for Migration, 13-6.

[57]. PerangkaanPengajianTinggi Malaysia, MOHE (2009) Data Handbook from Research and Development Unit of the Ministry of Higher education. Published by MOHE.

[58]. Robertson, R. (2003). The three waves of globalization: A history of a developing global consciousness.Black Point, N.S.: Fernwood.

[59]. Roberston, R., \&Scholte, J. A. (2007). Encyclopedia of globalization (Vols.1-4). New York, NY: Routledge.

[60]. Robertson, S. L. (2008). Europe/Asia regionalism, higher education and the production of world order. Policy Futures for Education, 6 (6), 718-729.

[61]. Rodney, W. (1972). How Europe Underdeveloped Africa. Tanzania publishing House, Dar-es-salaam, Tanzania.

[62]. Social \& Economic Survey Research Institute (SESRI) 2010 First Annual Omnibus Survey: ASurvey of Life in Qatar. Executive Summary Report. SESRI, Doha.

[63]. Slaughter, S., \& Leslie, L. (1997). Academic Capitalism: Politics, Policies, and the Entrepreneurial University. Baltimore, MD: The John Hopkins University Press.

[64]. Slaughter, S., \& Rhoades, G. (2004). Academic Capitalism and the New Economy: Markets, State and Higher Education.Baltimore, MD: The Johns Hopkins University Press.

[65]. Spring, J. (2009) Globalization of Education: An Introduction. Queens College \& Graduate Centre, City university of New York

[66]. Smith, D. (1987). The Everyday World as Problematic: A Feminist Sociology. Toronto: University of Toronto Press.

[67]. Smith, D. (1990a). The Conceptual Practices of Power: A Feminist Sociology of Knowledge. Toronto: University of Toronto Press

[68]. Tefferra,D. and Altbach, P.G. (eds.)(2003). African Higher Education: An International Reference Handbook. Bloomington: Indiana University Press.

[69]. Todaro, Michael.P. (1976). Internal migration in developing countries. Geneva: International Labor Office

[70]. Tsvetkova, N. (2008). International education during the Cold War: Soviet Social transformation and American social reproduction. Comparative Education Review, 52 (2), 199-217.

[71]. Turner, Y., \& Robson, T. (1987), Globalization and its Impact on Higher Education. East-Hall publishers, Canada

[72]. Tillman, G. (1989). The infrastructure of international cooperation in Canadian universities: Evolution from 1985-1988.Ottawa, Ont::Association of Universities and Colleges of Canada, International.

[73]. Usher, A., \& Dunn, R. (2009). On the brink: How the recession of 2009 will affect post-secondary education. Toronto, ON: Educational Policy Institute. Retrieved from http://www.educationalpolicy.org

[74]. United Nations Educational, Scientific and Cultural Organization UNESCO. (2006). Global education digest 2006: Comparing education statistics across the world. Retrieved fromhttp://www.uis.unesco.org/

[75]. United Nations Educational, Scientific and Cultural Organization (UNESCO). (2004). Higher Education in a Globalized Society. France, Paris: UNESCO Publishing.

[76]. UNESCO. (2006). Global Education Digest 2006: Comparing education statistics across the world.Retrieved from http://www.uis.unesco.org/TEMPLATE/pdf/ged/2006/GED2006.pdf

[77]. Verbik, L., \&Lasanowski, V. (2007). International student mobility: Patterns and trends. Retrieved fromhttp://www.obhe.ac.uk/documents/view_details?id=14.

[78]. Waters, M. (2001). Globalization. Key ideas. London: Routledge.

[79]. World Bank Group (2003). Foreign investment, remittances outpace debt as sources of finance for developing countries: World BankEurope and Central Asia.On line Dev News Media Centre, 2 April 2003, www.worldbank.org/prospects/gdf2003[accessed 2011 0910].

[80]. World Migration Report (2011). Communicating Effectively about Migration.OM 17 route des Morillons 1211 Geneva 19 Switzerland.

[81]. World Bank 2010Migration and Development Brief 13. Outlook for Remittance Flows2011-12. World Bank, Washington, DC. See: http://siteresources.

[82]. Yang, R. (2005). Internaitonalizing Chinese higher education: A case study of a major comprehensive university. In P. Ninnes\& M. Hellsten (Eds.), Internationalizing higher education:Critical explorations of pedagogy and policy(pp. 97-118). Hong Kong: Comparative Education Research Centre.Zimmermann, K.F. (1995). Tackling the European migration problem. Journal of Economic Perspectives, 9, $46-47$. 